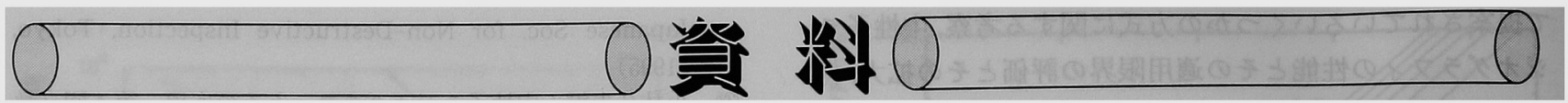

\title{
TRU廃棄物処分場への人間侵入の観点から見た 地下構造物深度分布調查
}

\author{
坂本 義昭*, 妹尾 宗明**, 杉本 純一郎**, \\ 大石 清隆**, 置塩 正則汭, 清水 全生**
}

\author{
Survey on Depth Distribution of Underground Structures for Consideration of \\ Human Intrusion into TRU Waste Repository \\ By Yoshiaki SAKAMOTO, Muneaki SENOO,
Junichiro SUGIMOTO, Kiyotaka OHISHI,
Masanori OKISHIO and Haruo SHIMIZU
}

\begin{abstract}
Depth distributions of some kinds of underground structure in Japan have been investigated to get an information about suitable depth of underground repository for TRU waste that is arising from reprocessing and MOX fuel fabrication plants. The underground structures investigated in this work were foundation pile of multistoried building, that of elevated expressway, that of JR shinkansen railway, tunnel of subway and wells. The major depth distribution of the underground structures except for the wells was in range from 30 to $50 \mathrm{~m}$, and their maximum depth was less than $100 \mathrm{~m}$. On the other hand, the $99 \%$ of wells was less than $300 \mathrm{~m}$ in depth. Maximum depth of the other underground structures has been also investigated for a survey of the utilization of underground by artificial structures in Japan.
\end{abstract}

KEYWORDS : TRU waste, human intrusion, depth distribution, depth, spatial distribution, underground structure, well, subway tunnel, foundation pile, underground facilities, underground disposal, underground storage

\section{I. まえがき}

使用済燃料の再処理施設およびMOX燃料加工施設から 発生する放射性廃亳物のうち, 高レベル廃液を除く廃棄物 は, 半減期が長く， $\alpha$ 放射体が多いTRU 核種を含むこ之 から，低レベル放射性廃棄物扝よび高レベル放射性廃棄物 と区別し「TRU 核種を含む放射性廃棄物」として別途その 処分方策が検討される(1)。このTRU 核種を含む放射性廃 棄物のうち, 放射能濃度が区分目安值 (約 $1 \mathrm{GBq} / \mathrm{t}$ )よりむ 低い放射能濃度を含む廃棄物は低レベル放射性廃棄物とし て浅地中炕分が, 放射能濃度が区分目安值よりす高い廃棄 物はTRU廃棄物として浅地中以外の地下埋設処分が考え られている(1)。これらの廃棄物については, それぞれの特 性を考慮して人工バリア性能, 処分深度等に関して合理的 な処分概念について検討がなされる(1)。

処分概念の検討において, 基本的で重要な要件の 1 つ しては処分深度の設定が挙げられる。放射能濃度が区分目 安值以下の浅地中処分に相当するTRU核種を含む放射性

*日本原子力研究所 (Japan At. Energy Res. Inst.)

** 財)原子力環境整備センター (Radioactive Waste Manage. Center)

** 佐藤工業(侏) (Sato Kogyo Co., Ltd.)

(1995年 7 月 6 日 受理), (1996年 2 月 7 日 再受理)
廃菓物の処分深度としては, 青森県六ヶ所村の低レベル放 射性廃棄物埋設眝蔵センターおよび諸外国の例から考える とおおむね十数 $\mathrm{m}$ から $30 \mathrm{~m}$ 程度 ${ }^{(2)}$ までが対象となる。し かし, TRU廃棄物の場合には, 浅地中以外の地下埋設処 分との考えから，その検討対象となる深度は，約 $30 \mathrm{~m}$ 以 深の比較的浅い深度から深地層までのかなり幅を有するも のとなる。このようなTRU廃棄物の処分深度を検討する に当たっては, 放射性核種の地下水移行シナリオによる検 討ととあに，人間侵入の可能性がなるべく小さくなるよう な深度を, 経斉的な観点からも考虑して合理的に設定する ことが 1 つの検討方法として想定される。このような観点 から, TRU廃棄物処分場への人間侵入の形態とその発生 頻度について整理することは, TRU廃棄物の処分深度の 設定における 1 つの基礎資料となると思われる。

本報においては, 我が国における地下構造物建設による TRU 廃宩物処分場やその近傍への人間侵入の可能性につ いて検討するための基礎資料として，いくつかの代表的な 地下構造物に対してその利用深度分布を調べた結果につい て報告する。本報では，同等な形態を有する地下構造物に ついての深度分布調查を実施したが，これら以外の既存の 地下構造物の最大深度も調查し, 我が国における地下構造 物の地下利用形態の概略を示した。さらに，将来の地下利 
用形態の動向を調へるため，新聞その他に公表された地下 構造物の建設計画·構想についてあ収集·整理した。

\section{II. 調 查対象}

地下約 $30 \mathrm{~m}$ 以深の地下も利用し，ある程度データがま とまっている例として，建築物基礎杭，地下鉄トンネルお よび梁井戸を調查対象として選定した。具体的に調查対象 とした構造物を第 1 表に示す。建築物基礎杭は，高層また は重量建筑物を支えるため比較的深い深度まで侵入してい る例である。地下鉄トンネルは，都市部において比較的大 きな断面積により地下を利用する形態の 1 つである。潹井 戸は，比較的深い地缯に設置される TRU廃棄物処分場を 想定した場合に考虑すべき人間侵入形態の1つである。

第 1 表 調查対象地下構造物

\begin{tabular}{|c|c|c|}
\hline 形 態 & & 対象構造物 \\
\hline \multirow[t]{3}{*}{ 基硶杭 } & 高層建築物 & $\begin{array}{c}\text { （日本建築センターで評定を受け } \\
\text { た高層建築物） }\end{array}$ \\
\hline & 道路高架部 & （首都高速道路） \\
\hline & $\mathrm{JR}$ 新幹線高架部 & （東海道，山陽，東北，上越新幹線） \\
\hline トンネル & 地下鉄 & （東京都営および営団地下鉄） \\
\hline 深井戸 & 澡井戸 & （国土庁の全国深井戸調書） \\
\hline
\end{tabular}

（）内は，具体的な対象物を示す。

\section{III. 調 查 方 法}

\section{1. 高層建築物の基礎杭}

高層建築物に関しては，(盺日本建築センターの評定を受 けることが義務づけられている。このために建築物の概要 をまとめた「性能評定シート」を日本建筑センターに出向い て収集·整理した。その結果，対象之なった高層建筑物は 598棟であった。本調查では，評定シートに明示されてい るデータから利用㳭度(基礎底深さ, 杭先端梁さ)について 整理した。

\section{2. 首都高速道路高架部}

調查対象は，地質区分から基礎杭が樑いと想定される以 下の路線とした。

·高速 1 号線(羽田・上野線 多摩川一北上野)

- 高速 6 号線(向島線 日本橋兜町一小营)

·高速 7 号線(小松川線 画国一谷河内)

·高速 9 号線(深川線 箱崎一辰巳)

・高速湾岸線(昭和島一市川市)

・高速中央環状線(葛飾一江戸川·臨海町)

調查は各路線の断面図を日本道路公団において入手し， この断面図を基に行った。本調查では，線状構造物の特性 を表現するために基礎杭の深度に対する対象路線の延長 で，深度別頻度を表すこととした。道路高架部の基礎構造 物の杭深さおよび基礎構造物を中心とする両側の道路高架
部の長さを読み取り，各道路高架部の長さの $1 / 2$ の和を当 該杭深度に対応する路線延長とした。

\section{JR 新幹線高架部の基礎杭}

$\mathrm{JR}$ 新幹線工事に扔いては，工事誌作成の一環として路 線縦断, 構造種別等を地質縦断図の中に整理している。本 調査では，JRに执いてこの地質縦断図を入手し，これを 基に基礎杭の深度別延長を調查した。調查方法は，前節 2.首都高速道路高架部之同様である。

\section{4.地下鉄トンネル}

調查対象としたのは，東京都心部の地下鉄(営団地下鉄, 都営地下鉄)で地下 $30 \mathrm{~m}$ 以深の区間を含む以下の路線とし た。

・営団干代田線(綾瀬一代々木上原)

・営団有楽町線(和光一新木場)

・都営新宿線(新宿一本八幡)

・営団半蔵門線(渋谷一三越前)

・都営12号線 放射部：新宿一光が丘,

環状部：新宿一(環状)一西新宿

調查方法は，各路線の䌅断面図を入手し，この縦断面図 から構造物の底部の深度および深度別 $(0 \sim 30 \mathrm{~m}, 30 \mathrm{~m}$ 以上 は $5 \mathrm{~m}$ 間隔)の区間距離を読み取り，整理した。

\section{5. 深井戸}

本調查では, 国土庁が国土調查法により「水調查(主要水 系調查)」および「水基本調查(深井戸台帳等)」を整理しデー タベース化した「全国深井戸調書」(1983年)を基にして実施 した。この「全国深井戸調書」には約 5 万数干本の井戸に関 する所在地, 用途, 深度, 口径等が記載されている。この調 書に収録されている井戸のうち，深度が判明している 51 ,550本を対象とし，それぞれのさく井年，深度，位置，用 途を調查した結果加深井戸の深度分布等を整理した。

\section{IV. 調 查 結 果}

\section{1. 建筑物基礎杭}

調查対象となった高層建築物の平均高さは約 $85 \mathrm{~m}$ であ り，基礎杭の平均深度は $24.5 \mathrm{~m}$ であった。また，最浅の 基礎杭は $2 \mathrm{~m}$, 最深は $65 \mathrm{~m}$ であった。高層建築物基礎杭の 深度分布を第 1 図(a)に示す。高層建築物の基礎杭深度は, 深度 $25 \mathrm{~m}$ において利用頻度が最大となり, 深度 $30 \mathrm{~m}$ を越 すと急激に減少する結果となった。累樍頻度を見ると，深 度 $40 \mathrm{~m}$ までで $90 \%$ であり，深度 $60 \mathrm{~m}$ で約 $100 \%$ となった。

首都高速道路高架部の基礎杭の地下深度利用に対する道 路の延長を第 1 図(b)に示す。この場合には，樑度 $60 \mathrm{~m}$ 程 度までのものが大半を占めており，最深のもので $80 \mathrm{~m}$ ま でであった。 

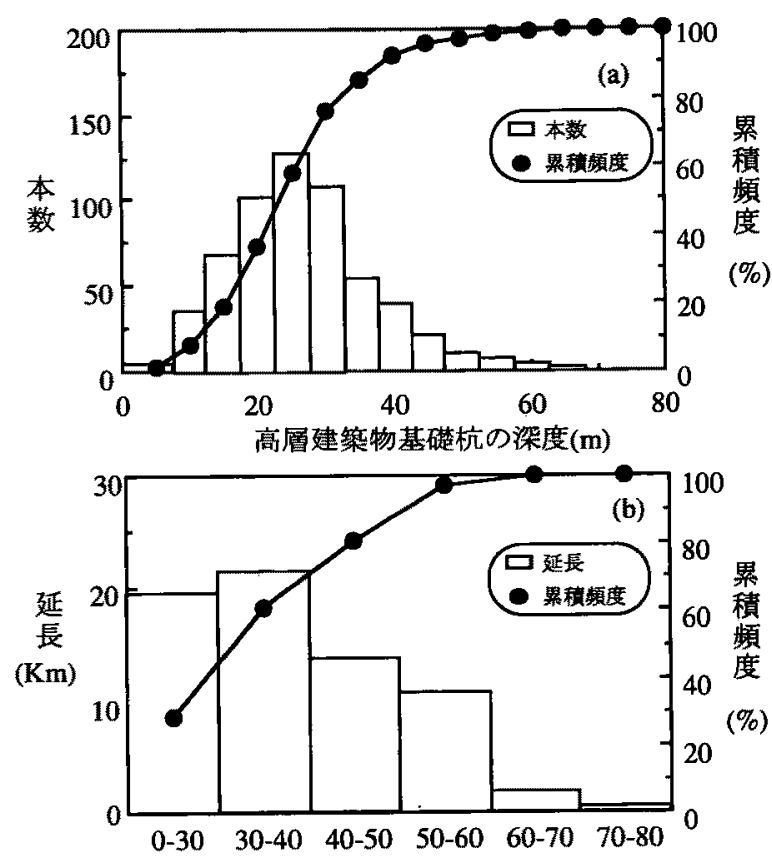

首都高速道路高架部基礎杭の深度(m)

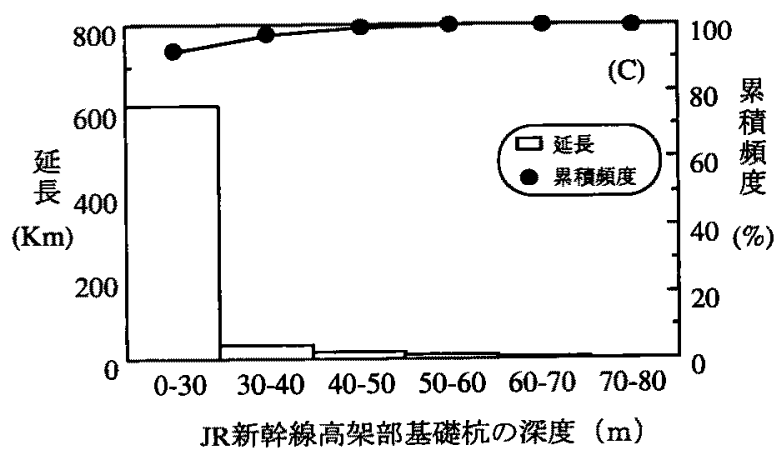

(a) 高層建築物基儊杭

(b) 首都高速道路高架部基整杭

(c) JR 新幹線高架部基脴杭

第 1 図 建築物等の基礎杭深度分布

$\mathrm{JR}$ 新幹線高架部基礎杭の地下利用深度分布を第 1 困(c) に示す。最大深度は $60 \mathrm{~m}$ であった。新幹線高架部基礎杭 の場合，そのほとんどが $30 \mathrm{~m}$ 以浅であり，深度 $30 \mathrm{~m}$ を越 える香のは全体の $12 \%$ あった。これらの建築物の基礎杭 の深度は，建築物の大きさと支持層の深度により異なるも のであるが，今回の調查ではどの基礎杭の深度分布もほぼ $80 \mathrm{~m}$ 以浅に収まる結果となった。

2. 地下鉄トンネル

東京都内の $30 \mathrm{~m}$ 以深部を含む地下鉄の深度に対する延 長を第 2 図に示す。地下鉄トンネルの場合は, 最大利用深

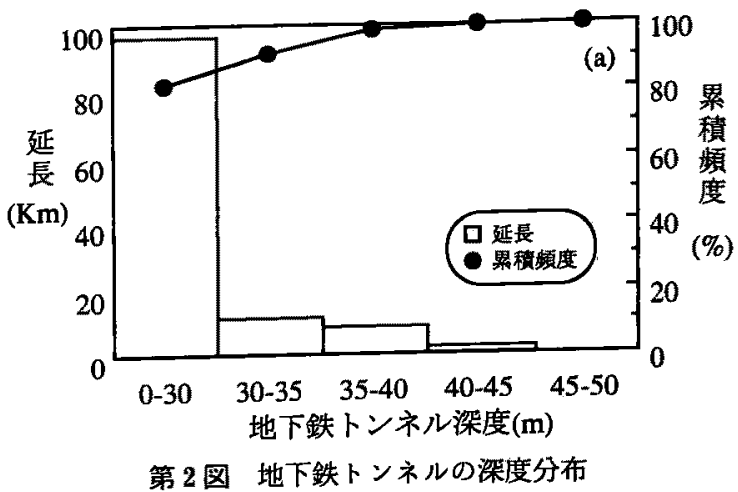

度は $45 \mathrm{~m}$ であり，利用深度の大半が $30 \mathrm{~m}$ 以浅であった。

3. 深井戸

本調查での深井戸の利用深度の平均は約 $98 \mathrm{~m}$ であった。 しかし，「全国深井戸調書」における深度のデータ記述が 3 桁に制限されているため, 最深の深度はすべて $999 \mathrm{~m}$ と記 述されている。したがって, 奉際は深度 $1,000 \mathrm{~m}$ 以上の皇 のあ含まれていると推定されるが，ここでは $999 \mathrm{~m}$ と記載 されている深井戸の深度は $1,000 \mathrm{~m}$ として平均深度を算出

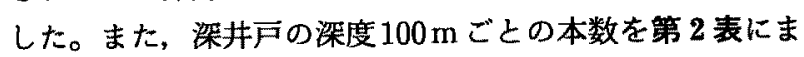
とめる。
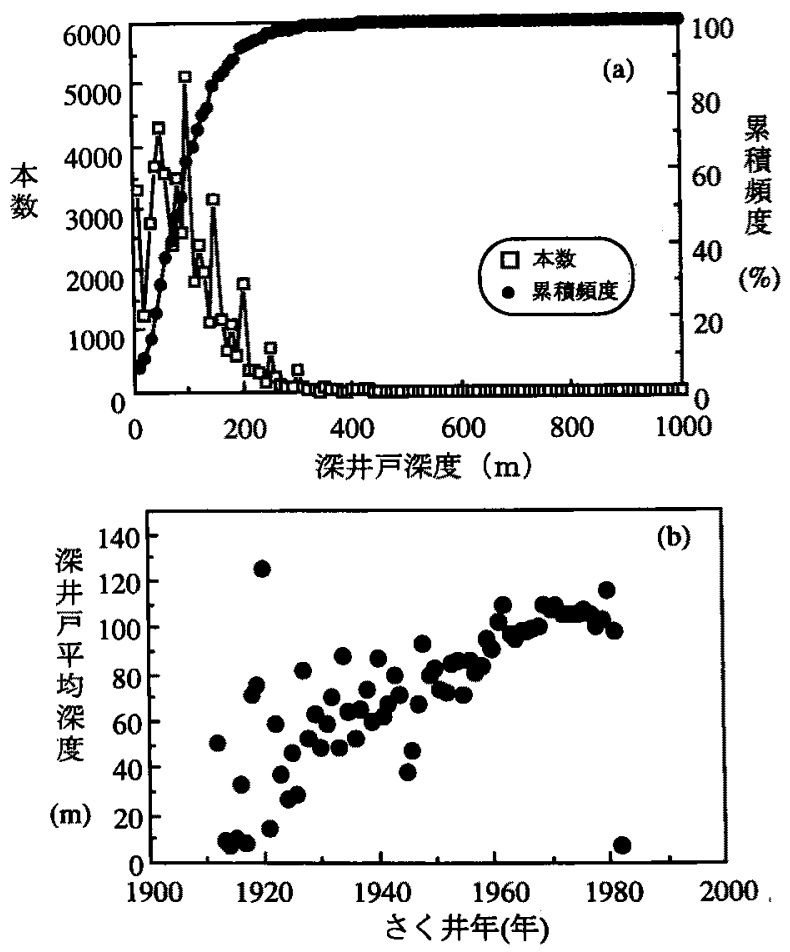

(a) 樑度分布わよび累積頻度

(b) 深井户平均深度のさく井年による推移

第 3 図深井戸の深度分布

第 2 表 樑度別深井戸本数

\begin{tabular}{lccccccccccc}
\hline 深度 & $\sim 30 \mathrm{~m}$ & $\sim 100 \mathrm{~m}$ & $\sim 200 \mathrm{~m}$ & $\sim 300 \mathrm{~m}$ & $\sim 400 \mathrm{~m}$ & $\sim 500 \mathrm{~m}$ & $\sim 600 \mathrm{~m}$ & $\sim 700 \mathrm{~m}$ & $\sim 800 \mathrm{~m}$ & $\sim 1,000 \mathrm{~m}$ & $1,000 \mathrm{~m}$ 以深 \\
\hline 本数 & 7,318 & 25,154 & 15,746 & 2,729 & 387 & 134 & 29 & 17 & 10 & 8 & 18 \\
\hline
\end{tabular}


深井戸の地下利用深度分布を第 3 图(a)に示す。深度 30 $\mathrm{m}$ 以浅では深井戸の累積頻度は，全体の約 $14 \%$, 深度 100 $\mathrm{m}$ 以浅では約 $63 \%$, 深度 $300 \mathrm{~m}$ 以浅で約 $99 \%$, 深度 $600 \mathrm{~m}$ 以 浅では約 $99.9 \%$ を占める結果となった。第 3 図(b)には, さく井年に対する深井戸の各年での平均深度を示す。明ら かに年と共に深井戸の平均深度が増加する結果となった。 しかし，1960年代以降，平均深度は約 100 120 m で頭打 ちの傾向が見られた。

また，第 3 表に深井戸の本数と平均深度を目的別にま之 めた結果を示す。特殊な利用目的である観測用を除き，農 業, 工業, 雑(温泉, 消雪等), 水道のどの利用目的もほぼ同程 度の本数であった。しかし, 平均深度は観測, 工業, 雑, 水 道がほぼ深度 $100 \mathrm{~m}$ 前後であったのに対して，農業用井戸 の平均深度が $67 \mathrm{~m}$ と他の利用目的より香浅い結果であっ た。さに，都市区分ごとの樑井戸の本数と平均深度を第 4 表に示す。人口 10 万人以上の都市を境にして，深井戸の 本数はほぼ半数ずつに区分されることがわかる。平均深度 は，人口 10 万人以上の都市では $100 \mathrm{~m}$ 前後であるが，人口

第 3 表 深井戸の目的別本数之平均深度

\begin{tabular}{lcc}
\hline 目 的 & 本 数 & 平均深度 $(\mathrm{m})$ \\
\hline 農 業 & $11,240(21.8 \%)$ & 67 \\
工 業 & $11,387(22.1)$ & 110 \\
雑 & $12,481(24.2)$ & 98 \\
水 道 & $11,376(22.1)$ & 113 \\
観 測 & $690(1.3)$ & 123 \\
不明 & $4,367(8.5)$ & 95 \\
\hline
\end{tabular}

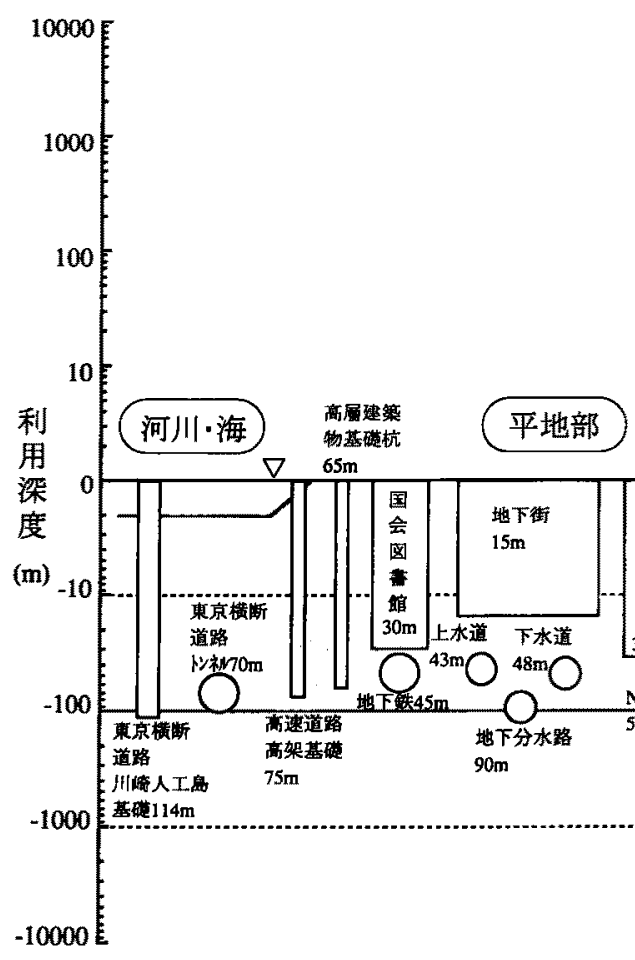

第 4 表 深井戸の都市区分別本数と平均深度

\begin{tabular}{lrc}
\hline \multicolumn{1}{c}{ 区 分 } & \multicolumn{1}{c}{ 本 数 } & 平均深度 $(\mathrm{m})$ \\
\hline 東京都23区内 & $2,082(4.0 \%)$ & 122 \\
人口100万人以上の都市 & $4,823(9.4)$ & 93 \\
人口10万人以上の都市 & $17,023(33.0)$ & 113 \\
その他 & $27,622(53.6)$ & 87 \\
\hline
\end{tabular}

10万人以下の都市では若干浅い樑度となった。

比較的深い地層人の処分場建設の場合における人間侵入 の対象として，500 $\mathrm{m}$ を越える深井戸(調查全体の約 0.2\%)について深度や用途等を第 5 表にまとめる。なお, 「全国深井戸調書」で $999 \mathrm{~m}$ 之記述されている深井戸につい ては，実際の深度を別に調査を行った結果を記載した。本 調查での深井戸の最大深度は $2,146 \mathrm{~m}$ であり, 深度 $500 \mathrm{~m}$ 以上の㳭井戸の平均潹度は $779 \mathrm{~m}$ であった。用途が記載さ れている井戸43本の内訳は，21本が温泉(浴用を含む)，上 水道等の飲用が 10 本, 地盤沈下観測が 8 本, その他 4 本で あった。

なお，「全国深井戸調書」に記載されていない類似構造物 として地熱発電用井戸, 地震観測井戸があり，深度 3,000 m以上のあの存在した。

\section{V、調査結果のまとめ}

上記の調查結果に加えて，他の既存の地下構造物の最大 深度についての調查結果を整理し，第 4 図にまとめる。こ の結果, 深井戸を除く地下構造物の最大深度はおおむね $100 \mathrm{~m}$ 前後であった。また，第 6 表に現時点で将来予測さ

第 4 図 既存地上粠造物の最大樑度分布 山岳部に存在する地下構造物は, 土被りを含む深度を示す。 
第 5 表 深度 $500 \mathrm{~m}$ を超える深井戸の用途等

\begin{tabular}{|c|c|c|c|c|c|c|c|c|c|c|c|}
\hline No. & 都道府県 & さく井年 & 深度(m) & 目的 & 用途 & No. & 都道府県 & 上<井年 & 深度(m) & 目的 & 用途 \\
\hline 1 & 千葉 & 1971 & 2146 & 䔘測用 & 地盤沈下観测 & 36 & 千葉 & - & 650 & 钼測用 & 地盤汇下锶测 \\
\hline 2 & 三重 & - & 1880 & 雑用 & - & 37 & 宮城 & 1958 & 615 & 雑用 & - \\
\hline 3 & 新潟 & 1940 & 1708 & 雑用 & 石油 & 38 & 新潟 & 1949 & 612 & 水道用 & 上水道 \\
\hline 4 & 三重 & - & 1540 & 雑用 & - & 39 & 新渴 & - & 611 & 水道用 & 上水道 \\
\hline 5 & 北海道 & 1974 & 1370 & 雑用 & 温泉 & 40 & 青森 & 1971 & 610 & 水道用 & 飲雑用 \\
\hline 6 & 北海道 & 1980 & 1201 & 雓用 & 温泉 & 41 & 北海道 & 1960 & 606 & 雑用 & 天然オ゙ス \\
\hline 7 & 北海道 & 1976 & 1200 & 雑用 & 温泉 & 42 & 大阪 & 1964 & 604 & 観測用 & 地盤沈下観測 \\
\hline 8 & 北海道 & 1978 & 1105 & 㕮用 & 温泉 & 43 & 青森 & 1971 & 601 & 工業用 & - \\
\hline 9 & 聯賀 & 1968 & 1097 & 雑用 & - & 44 & 山形 & 1978 & 601 & 雑用 & 浴用 \\
\hline 10 & 青森 & 1976 & 1059 & 雜用 & 温泉 & 45 & 青森 & - & 600 & 水道用 & 上水道 \\
\hline 11 & 千葉 & - & 1050 & 筧湘用 & 地盤沈下観測 & 46 & 北海道 & 1973 & 600 & 雑用 & 温泉 \\
\hline 12 & 北海道 & 1978 & 1000 & 雑用 & 温泉 & 47 & 青森 & 1971 & 600 & 雑用 & - \\
\hline 13 & 北海道 & 1977 & 950 & 雓用 & 温泉 & 48 & 埼玉 & 1973 & 600 & 観測用 & 地盤沈下襯測 \\
\hline 14 & 青森 & 1974 & 944 & 䧴用 & - & 49 & 大阪 & 1976 & 600 & 雑用 & 她盤調查 \\
\hline 15 & 青森 & 1977 & 930 & 䧴用 & 温泉 & 50 & 山形 & 1976 & 595 & 雑用 & 温泉 \\
\hline 16 & 青森 & 1977 & 916 & 雑用 & 温泉 & 51 & 北海道 & 1934 & 570 & - & - \\
\hline 17 & 大阪 & 1963 & 907 & 䔘測用 & 地盤沈下観測 & 52 & 青森 & 1961 & 569 & 水道用 & 飲料水 \\
\hline 18 & 青森 & 1977 & 900 & 傕用 & - & 53 & 秋田 & - & 553 & - & - \\
\hline 19 & 新渺 & 1965 & 900 & - & - & 54 & 東京 & - & 553 & 雑用 & - \\
\hline 20 & 青森 & 1978 & 801 & 雑用 & 一 & 55 & 新潟 & - & 551 & 雑用 & 温泉 \\
\hline 21 & 北海道 & 1976 & 800 & 雑用 & 温泉 & 56 & 青森 & 1972 & 550 & 水道用 & 上水道 \\
\hline 22 & 北海道 & 1980 & 800 & 雑用 & 温泉 & 57 & 新渴 & 1968 & 541 & - & - \\
\hline 23 & 青森 & 1980 & 800 & 雑用 & - & 58 & 三重 & - & 540 & 雑用 & - \\
\hline 24 & 山形 & 1975 & 776 & - & - & 59 & 山形 & 1947 & 525 & - & 一 \\
\hline 25 & 青森 & 1977 & 756 & 檴用 & - & 60 & 千葉 & - & 520 & 観測用 & 地盤沈下镜測 \\
\hline 26 & 青森 & 1977 & 750 & 傕用 & - & 61 & 千㷛 & 1973 & 520 & 工業用 & - \\
\hline 27 & 秋田 & 1963 & 720 & 雑用 & - & 62 & 北海道 & 1953 & 510 & 雑用 & 温泉 \\
\hline 28 & 秋田 & 1953 & 720 & 水道用 & 上水道 & 63 & 青森 & 1970 & 508 & 水道用 & 领雑用 \\
\hline 29 & 青森 & 1979 & 703 & 雑用 & 一 & 64 & 青森 & 1974 & 508 & 雑用 & - \\
\hline 30 & 北海道 & 1976 & 700 & 雜用 & 温泉 & 65 & 北海道 & 1955 & 503 & 雑用 & 天然ガス \\
\hline 31 & 埼玉 & 1972 & 700 & 隺測用 & 地盤沈下観測 & 66 & 青森 & 1974 & 503 & 水道用 & 饮雑用 \\
\hline 32 & 神奈川 & 1975 & 700 & 雑用 & 温泉 & 67 & 北海道 & 1974 & 501 & 雜用 & 温泉 \\
\hline 33 & 京都 & 1961 & 700 & 水道用 & 上水道 & 68 & 北海道 & 1975 & 501 & 雑用 & 温泉 \\
\hline 34 & 三重 & - & 700 & 歎用 & 一 & 69 & 秋田 & 1956 & 501 & 雑用 & - \\
\hline 35 & 青森 & 1970 & 666 & 雑用 & 温泉 & & & & & & \\
\hline
\end{tabular}

一は記載無し

第 6 表 将来予測される地下構造物とをの澡度

\begin{tabular}{|c|c|c|c|}
\hline 項目 & 主な計画・構想 & 利用深度 & 参考文献 \\
\hline 産業 & 地下生コン工場構想 & $30 \mathrm{~m}$ & (3) \\
\hline 通信·情報システム & 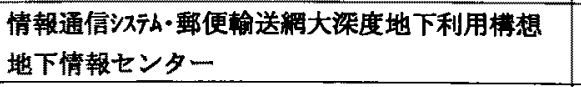 & $\begin{array}{l}50 \mathrm{~m} \text { 以深 } \\
50 \mathrm{~m} \text { 以深 }\end{array}$ & $\begin{array}{l}(4) \\
(5)\end{array}$ \\
\hline 交通 & ジオポート桙想(地下エアターミナル) & $50 \sim 150 \mathrm{~m}$ & (6) \\
\hline 環境防災 & 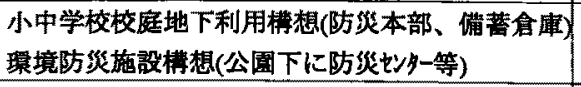 & $\begin{array}{l}19 \mathrm{~m} \\
57 \mathrm{~m} \\
\end{array}$ & $\begin{array}{l}(7) \\
(8)\end{array}$ \\
\hline 廃萧物 & 地下型污泥コンポスト施設棬想 & $45 \mathrm{~m}$ & (9) \\
\hline 電力・エネルギー & 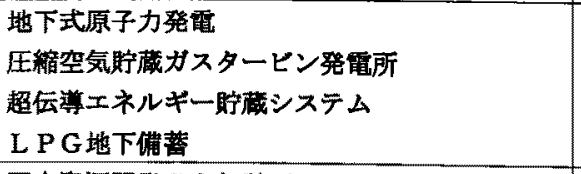 & $\begin{array}{c}100 \sim 150 \mathrm{~m} \\
400 \sim 700 \mathrm{~m} \\
120 \mathrm{~m} \\
100 \text { 数 }+\mathrm{m} \\
\end{array}$ & $\begin{array}{l}(10) \\
(11) \\
(12) \\
(13) \\
\end{array}$ \\
\hline 摆源 & 国内资源開発 5 力年計画 & $5000 \sim 6300 \mathrm{~m}$ & (14) \\
\hline 研究・開発 & 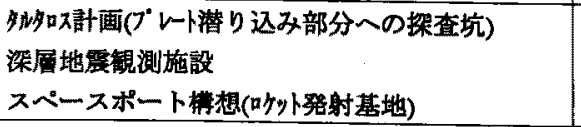 & $\begin{array}{c}10000 \sim 15000 \mathrm{~m} \\
2000 \sim 3000 \mathrm{~m} \\
2000 \mathrm{~m}\end{array}$ & $\begin{array}{l}(15) \\
(16) \\
(17)\end{array}$ \\
\hline
\end{tabular}


れるいくつかの地下構造物の澡度について示す。

以上の調查結果は，限られた例ではあるが日本全国の平 均的亡思われる地下構造物を取り上げ，その深度分布につ いて整理したものである。この結果，深井戸以外の地下構 造物においては，30 $50 \mathrm{~m}$ 程度が主要な利用深度であり， 最大深度むおおむね $100 \mathrm{~m}$ 以浅であった。深井戸の場合に は, 最大利用深度は深地層の処分場として想定される深度 1,000 $\mathrm{m}$ よりも深いむのの, 樑井戸の $99 \%$ は $300 \mathrm{~m}$ 以浅で の利用であった。これらのデータは，TRU廃衰物処分場 の澡度設定において，人間侵入によるリスクをある程度以 下になるように検討を行うための基礎資料として利用でき ると考えられる。しかし，すべての地下構造物を調查対象 にしたわけではないため，具体的な処分場における人間侵 入つ可能性については，例えば炕分候補地での帯水層の深 度分布や将来的な地下利用の可能性等に関しては，対象地 域の特性を考慮した検討が必要となるであろう。

最後に, 本調查の結果は, ここ数 10 年間での地下利用深 度の結果をまとめたものであるが，TRU廃裹物の処分に おいては数万年オーダーでの安全性評価が求められること から，このような長期の評価に直接的に利用できるかどう かについては, 今後の社会的な要因の考慮必必要である。
本調查は，科学技術㱙からの委託により実施された研究 の成果の一部である。

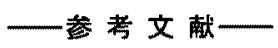

(1) 原子力委員会： "TRU核種を含む廃棄物の处理起分”, (1991).

（2）日本原子力産業会議：“放射性廃菓物管理ガイドブック”, 102(1994).

(3) 日刊建設工業新聞 1990 年 2 月 22 日付.

(4) 日刊建設工業新聞 1990 年 4 月16日付.

（5）日本産業技振協・エンジニアリング振協：地下空間利用技術 に関するテクノロジーアセスメント，(1988).

(6) 日経産業新聞 1989年11月 1 日付.

（7）熊谷良雄：トンネルと地下，16，7 (1985).

(8) 日経産業新聞 1989年11月16日付.

(9) 日刊建設工業新聞 1989年 7 月16日付。

(10) 日比野 敏：電力土木, No.219, 54 (1989).

(11) 日本産業技振協・エンジニアリング振協：地下空間利用技術 に関するテクノロジーアセスメント，(1988).

(12) エンシニアリング振協：超伝導エネルギー眝蔵システム調查 研究報告書, (1986).

(13) プロジェクトウィークリー445号, (1990).

(14) プロジェクトウィークリー400号, (1990).

(15) 日本経済新聞 1988年6月16日付.

(16) 日刊工業新聞 1991年 2 月 7 日付.

(17) 日経産業新聞 1989年 5 月19日付.

\section{次先 端技術と原子力出 「原子カへの先端技術応用」研究專門委員会 成果報告書}

1996年 3 月発行（限定出版）好評発売中

A4判オフセット印刷,168頁，会員 3,000円 (定価 4,000円)(干 400円)

（ご希望の方は学会事務局へ（TEL 03-3508-1261；FAX 03-3581-6128）

「原子力への先端技術応用」研究専門委員会は，1994年 4 月から 96 年 3 月まで 2 年間にわたり，原子力の分野に関係 する広範囲の先端技術に関する情報を調查し，積極的に応用するための活動を行ってきた。

本報告書は，1994年度の報告書に続く 2 年目の成果をまとめたもので，昨 (1995) 年 8 月に 1 日半をかけて開催した シンポジゥムと本年 3 月に行った研究専門委員会の講演内容をまとめたものである。原子力に関連した先端分野の技 術の最新の動向を知ることができるむのと期待される。

\section{目 次 (概 要)}

\section{I. シンポジウム}

1. 理工科学研究の先端性と調和

2. 原子力研究と基礎科学

3. 核融合開発研究における先端性

4. 光技術を用いた原子力計測

5. 放射光の材料への応用

6. 字宙放射線之生物

7. 炬心管理技術への遗伝アルゴリズム ・ニューラルネットワークの応用
8. 高レベル廃集物深地層処分の安全評価のための 地球科学的シミュレーション

II. 研究専門委員会

1. 低温化学反応におけるトンネル効果

2. 自由電子レーザーとその応用

3. 地層科学研究とその技術開発 